\title{
Managing Volatile Capital Flows Experiences and Lessons for Sub-Saharan African Frontier Markets
}

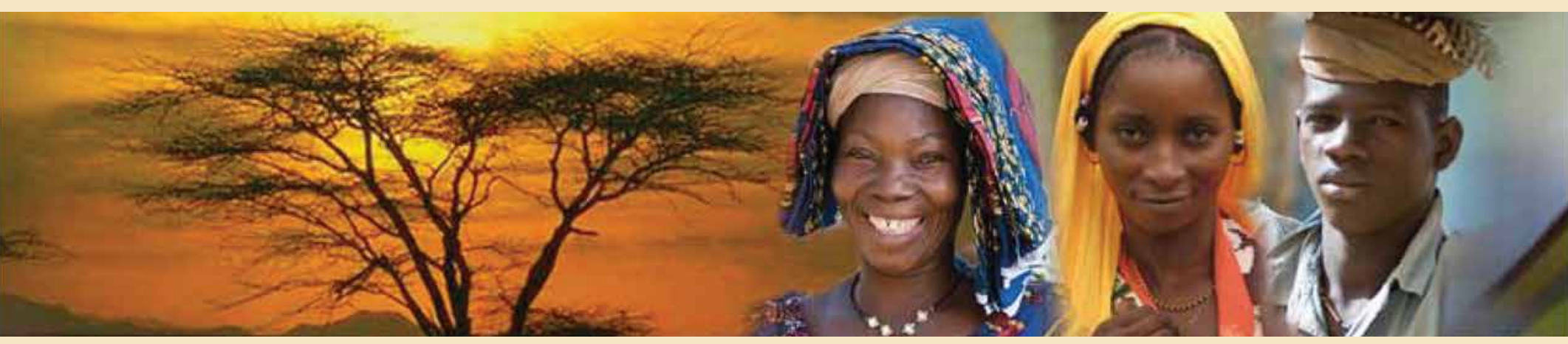

A Staff Team Led by Trevor Alleyne and Mauro Mecagni 


\section{Managing Volatile Capital Flows Experiences and Lessons for Sub-Saharan African Frontier Markets}

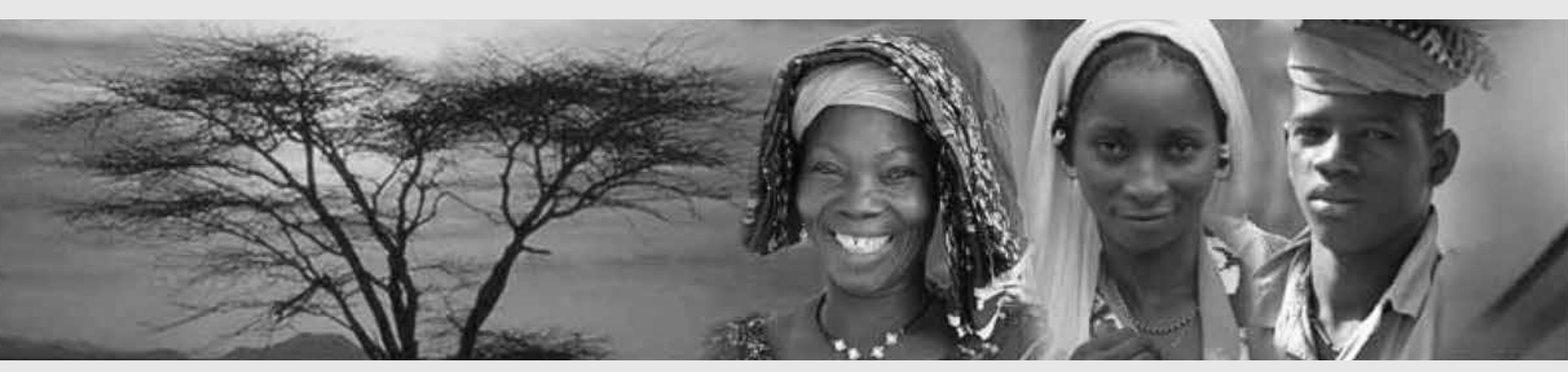

A Staff Team Led by Trevor Alleyne and Mauro Mecagni 


\section{(C) 2014 International Monetary Fund}

\section{Cataloging-in-Publication Data Joint Bank-Fund Library}

Alleyne, Trevor Serge Coleridge.

Managing volatile capital flows : experiences and lessons for SubSaharan African frontier markets / prepared by Trevor Alleyne [and eight others], under the guidance of Anne-Marie GuldeWolf. - Washington, D.C. : International Monetary Fund, 2014. pages. ; $\mathrm{cm}$

Includes bibliographical references.

ISBN: 978-1-61635-884-0

1. Capital movements-Africa, Sub-Saharan. I. Gulde, Anne-Marie. II. International Monetary Fund. III. Title.

HG3891.M36 2014

Disclaimer: The views expressed in this book are those of the authors and should not be reported as or attributed to the International Monetary Fund, its Executive Board, or the governments of any of its member countries.

Please send orders to:

International Monetary Fund, Publication Services

P.O. Box 92780, Washington, DC 20090, U.S.A.

Tel.: (202) 623-7430 Fax: (202) 623-7201

E-mail: publications@imf.org

Internet: www.elibrary.imf.org www.imfbookstore.org 


\section{Acknowledgments}

This Departmental Paper was prepared by Cheikh Anta Gueye, Javier Arze del Granado, Rodrigo Garcia-Verdu, Mumtaz Hussain, Byung Kyoon Jang, Sebastian Weber, and Juan Sebastian Corrales, with supervision by Trevor Alleyne and Mauro Mecagni, and under the guidance of Anne-Marie Gulde-Wolf. 



\section{Contents}

Acknowledgments

$\begin{array}{lr}\text { Introduction and Summary } & 1\end{array}$

1. Short-Term Flows in Sub-Saharan African Frontier Markets 3

Nature and Characteristics of Capital Flows 3

Macroeconomic Impact of Recent Portfolio Capital Flows 14

2. Policy Responses to Capital Flows in Sub-Saharan

$\begin{array}{ll}\text { Frontier Markets } & 17\end{array}$

Macroeconomic Policies $\quad 17$

Macroprudential Measures 19

Capital Flow Management Measures 22

$\begin{array}{lr}\text { Conclusions } & 25\end{array}$

Annex: Econometric Analysis of Drivers of Portfolio Flows to Sub-Saharan African Frontier Markets 27

$\begin{array}{ll}\text { References } & 31\end{array}$

Figures

Figure 1. Capital Inflows 3

Figure 2. Private Investment in Sub-Saharan Africa and Emerging Market

and Developing Economies 5

Figure 3. Sub-Saharan African Frontier Markets External Loans from and Deposits at BIS-reporting Banks

Figure 4. Trends and Fluctuations in Equity and Bonds Flows to Sub-Saharan African Countries

Figure 5. Sub-Saharan African Frontier Markets versus Selected Emerging Market and Developing Economies, Exchange Rate Depreciation

Figure 6. Sub-Saharan Africa versus Selected Emerging Market and Developing Economies, Exchange Rate Volatility, 2013

Figure 7. Sub-Saharan Africa Selected Economies, Government Bond Yield to Maturity Spreads to 10-year U.S. Bond, 2013

Figure 8. Sub-Saharan African Frontier Markets-Twin Deficit

Figure 9a. Sub-Saharan Africa Frontier Markets-Portfolio Flows and Government Bonds Yields 
Figure 9b. Sub-Saharan Africa Frontier Markets_-Portfolio Flows and Stock Prices Index

Figure 10. Sub-Saharan Africa Frontier Markets: Net Portfolio Flows and Gross International Reserves

\section{Boxes}

Box 1. Drivers of Portfolio Flows to Sub-Saharan African Frontier Markets

Box 2. Ghana's Recent Experience in Portfolio Flows 10

Box 3. Nigeria_Capital Flows and Policy Response 12

Box 4. Zambia-Copper and Capital 16

Box 5. Capital Flows Management Measures in Sub-Saharan African $\begin{array}{ll}\text { Frontier Markets } & 20\end{array}$

Box 6. Examples of Macroprudential Policies 23

Tables

Table 1. Sub-Saharan African Frontier Markets: Average Private Flows 6

Table 2. Cross-Border Bank-related Flows to Sub-Saharan African Countries

Table 3. Real Exchange and International Reserves Performance 18

Table A.1. Determinants of Portfolio Investment Flows 28

Table A.2. Determinants of Equity and Bond Flows in Sub-Saharan Africa 29 


\section{Introduction and Summary}

Over the last three years, the frontier market economies of sub-Saharan Africa have received growing amounts of portfolio capital flows. ${ }^{1}$ During the 2000s, sub-Saharan African frontier markets garnered growing interest from foreign investors, but heightened risk aversion from the Great Recession temporarily caused investors to retreat. Since 2010, continued positive macroeconomic performance, coupled with unprecedented accommodative monetary policies in advanced economies, renewed foreign investors' interest on a much larger scale, resulting in sub-Saharan African frontier markets becoming more integrated with international capital markets. The number of sub-Saharan African countries with international credit ratings has increased, a large number of countries issued sovereign bonds - many of them for the first time - and foreign investors have become active players in some domestic bond and equity markets.

Although these increased foreign capital inflows may supplement domestic financing of investment, they also pose challenges. Compared with foreign direct investment (FDI), portfolio capital flows and cross-border bank loans tend to be more volatile and more sensitive to changing conditions in global financial markets. Although thus far, most sub-Saharan African frontier markets have largely escaped the turbulence in financial markets suffered by emerging and developing countries in recent months, there is still the risk that, in the future, capital flow volatility may overwhelm relatively shallow financial markets of sub-Saharan African frontier markets and test the capacity of macroeconomic policies to adjust. Therefore, it is important for these countries to have in place or strengthen frameworks so as to manage vulnerabilities to sudden reversals, should the related risks materialize.

${ }^{1}$ In this paper, a relatively wide definition of frontier markets for sub-Saharan Africa is adopted. Criteria used to select countries include recent growth dynamics and prospects, financial market development, general institutional conditions and evolution, and political conditions and perspectives. Although some of the countries are not included in investment bank indices, there has been sufficient foreign investor interest over the past five to ten years to warrant their consideration here. The list includes Ghana, Kenya, Mauritius, Mozambique, Nigeria, Senegal, Tanzania, Uganda, and Zambia (IMF, 2011a). 
Against this background, this study examines the evolution of capital flows since 2010, in particular portfolio and cross-border bank flows in subSaharan African frontier markets. ${ }^{2}$ It discusses the macroeconomic policies and macroprudential policies that these countries have designed and/or implemented to reduce risks from the inherent volatility of these flows, and looks at how such policies might need to be strengthened as these countries become more integrated with the global financial system. It also examines the appropriate role for capital flow measures (CFMs).

Our analysis suggests that sub-Saharan African frontier markets should strengthen policy frameworks to ensure that access to capital markets is beneficial, specifically as these countries become more integrated with the global financial system and there is a need to reduce vulnerabilities associated with capital flow surges and capital reversals in the short term as well as in the long term. Therefore, the following recommendations are provided for subSaharan frontier markets economies:

- Improve data. The first step in being able to manage capital flows is to be able to monitor them effectively with data that are timely and of good quality. Article IV reports for most sub-Saharan African frontier markets have already highlighted the need to strengthen balance-of-payments data, including the coverage of cross-border private capital flows and stocks. ${ }^{3}$

- Enhance macroeconomic and financial policies. Managing capital flows is more likely to be successful if it is supported by sound fiscal, monetary, and exchange rate policies and adequate fiscal and international reserve buffers.

- Improve capacity to effectively use macroprudential policies. In sub-Saharan African frontier markets, supervisory resources, including qualified staff, the availability of high-frequency data, and analytical tools to assess systemic risks are limited and will need to be strengthened to ensure the effectiveness of macroprudential policies.

- Exercise caution in the use of capital flow management measures. The imposition of new CFMs could jeopardize further financial sector deepening and thus should be considered as a temporary measure in the context of managing a crisis or near crisis situation (IMF, 2012).

2 IMF (2011a) examined capital flow developments in sub-Saharan Africa up to 2009.

${ }^{3}$ A survey of the issues raised in the Article IV staff reports on the quality of data include (i) large net errors and omissions for the published balance of payments; (ii) data collection on transactions in nonresident securities is still a challenge; (iii) unreliable current/capital transfer split for foreign aid and no detailed data on the costs of embassies abroad; (iv) poor coverage of reinvested earnings; (v) data on outstanding debt stocks and principal payments are inconsistent; (vi) financial account is incomplete, as it does not record substantial transactions in assets; and (vii) flows and stocks of gross international reserves and net foreign assets position often require substantial adjustments. 


\section{Chapter}

\section{Short-Term Flows in Sub-Saharan African Frontier Markets}

\section{Nature and Characteristics of Capital Flows}

Over the last decade, private capital flows to sub-Saharan Africa grew considerably. In the past, Africa had to rely heavily on official resources to finance balance-of-payments needs. Since 2010, however, easy global financial conditions combined with sustained high growth and improved economic prospects led to a significant increase in private capital inflows to sub-Saharan African countries (Figure 1 and Box 1). Over the 2010-12 period, net private flows to sub-Saharan African countries doubled, from a low base, compared with the 2000-07 period; in the case of sub-Saharan African frontier markets, there has been a fivefold increase.

Figure 1. Capital Inflows ${ }^{1}$

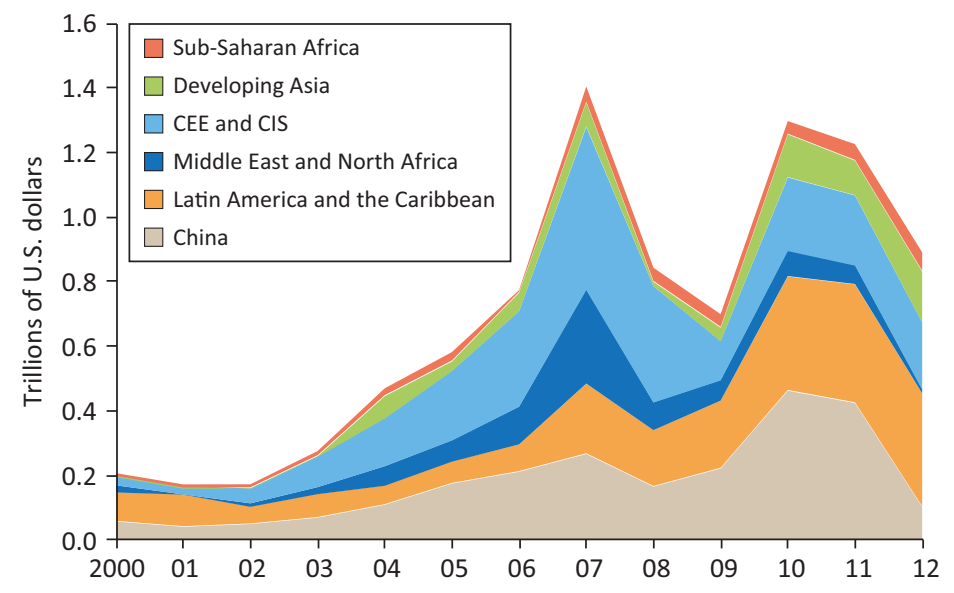

Source: IMF, World Economic Outlook database.

Notes: $\mathrm{CEE}=$ Central and Eastern Europe; CIS $=$ Commonwealth of Independent States. ${ }^{1}$ Capital inflows are defined as the aggregate of foreign direct investment, portfolio, and other liabilities. Category other includes liabilities to official creditors, foreign bank loans, and other financial transactions not covered in direct investment, portfolio investment, or reserve assets. 


\section{Box 1. Drivers of Portfolio Flows to Sub-Saharan African Frontier Markets}

Both push and pull factors contributed to the surge in portfolio private capital flows to sub-Saharan African frontier markets between 2011 and 2013:Q1. Push factors include weak economic growth, excess liquidity, and low bond yields in advanced economies. Pull factors include the better economic prospects in subSaharan African frontier markets. Improved macroeconomic policy management, low debt levels, and structural reforms, including related to the development of capital and securities markets, have encouraged foreign investment. Some factors, such as excess global liquidity, are cyclical; others, such as the positive potential growth differential between sub-Saharan African frontier markets and advanced economies, are structural and may persist. One important factor-investor risk aversion-is highly volatile, and can change abruptly in response to political as well as economic events.

An econometric analysis of the determinants of net portfolio flows in subSaharan African frontier markets did not yield convincing results. Although the global risk aversion variable (VIX) was negative, significant, and robust across many model specifications, none of the other push or pull factors were statistically significant-most likely because of a combination of factors, including poor data quality (see the Annex).

Table 1. Examples of Factors Affecting Capital Flows

\begin{tabular}{cll}
\hline & Cyclical & Structural \\
\hline $\begin{array}{c}\text { Push (from outside } \\
\text { sub-Saharan Africa) }\end{array}$ & - Interest rates in advanced & - International portfolio diversification \\
& - Global risk aversion & - Potential growth differential \\
& & between advanced and sub-Saharan \\
& African frontier markets \\
Pull (inside sub- & - Commodity prices & - Fiscal and external balance sheets \\
Saharan Africa) & - Domestic interest rates & - Trade openness and other reforms \\
& - Domestic inflation & - External capital account openness \\
& - Exchange rate stability & \\
\hline
\end{tabular}

Sub-Saharan African frontier markets were the main beneficiaries of the recent surge in private capital flows. Although FDI contributed largely to this trend, portfolio and cross-border bank flows also increased (Figure 2), surpassing the US $\$ 17$ billion mark in 2012. Ghana, Nigeria, and Zambia were the main beneficiaries among sub-Saharan African frontier markets (Table 1). ${ }^{4}$ These countries recorded portfolio flows estimated at about 1.9 percent of GDP, 2.7 percent of GDP, and 1.6 percent of GDP, respectively. For the other sub-Saharan African frontier markets, portfolio flows still remain quite small. Cross-border bank lending to sub-Saharan African frontier markets also rose (Table 2), but net deposit positions remained stable for banks as deposits in foreign banks grew steadily (Figure 3).

${ }^{4}$ For Senegal, IMF staff believes the official numbers to be unrealistically large. 


\section{Figure 2. Private Investment in Sub-Saharan Africa and Emerging Market and Developing Economies}
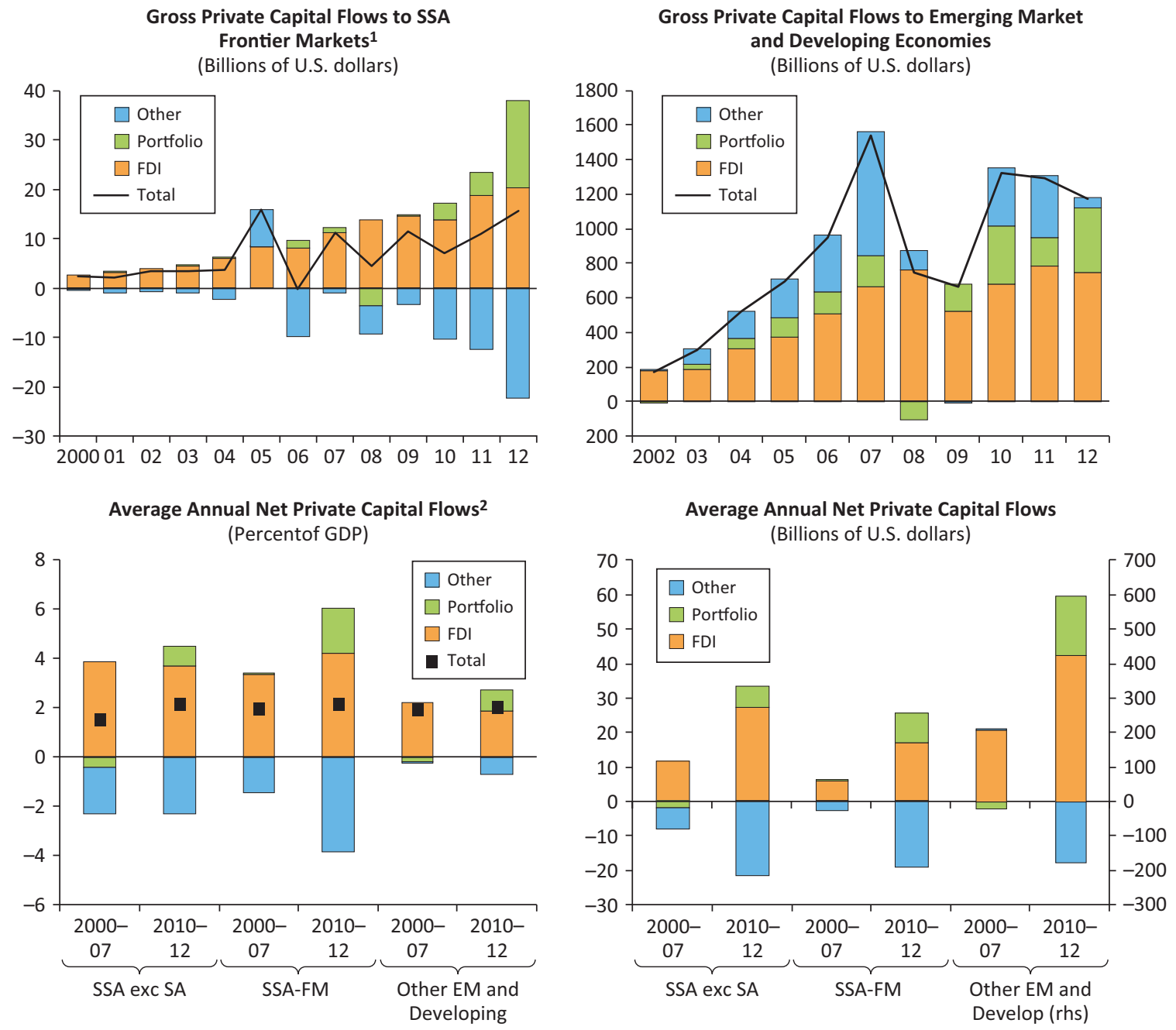

Source: IMF, World Economic Outlook (WEO).

Notes: $\mathrm{EM}=$ emerging markets; FDI = foreign direct investment; $\mathrm{FM}=$ frontier markets; rhs = right-hand scale; $\mathrm{SA}=$ South Africa; $\mathrm{SSA}$ = sub-Saharan Africa.

${ }^{1}$ Gross private capital flows are defined as the aggregate of liabilities related to FDI, Portfolio, and Other. Other investment is a residual category that includes short-and long-term loans, deposits, trade credits, and other financial transactions not covered in direct investment, portfolio investment, or reserve assets. Here liabilities to official creditors are excluded.

${ }^{2}$ The WEO follows the IMF's Balance of Payments and International Investment Position Manual, fifth edition, in which an increase in financial assets (outflow) is recorded as a negative number. On the other hand, an increase in financial liability (inflow) is recorded as a positive number. Thus, net flows are calculated as the sum of assets and liabilities. The category Other excludes liabilities to official creditors.

Although portfolio flows to sub-Saharan African frontier markets remain tiny compared with flows to other emerging and developing economies, their importance relative to country size is about equal. Over 2010-12, net portfolio flows to sub-Saharan African frontier markets still constitute a small share of total net portfolio flows to emerging and developing countries. 
Table 1. Sub-Saharan African Frontier Markets: Average Private Flows (Average percent of GDP)

\begin{tabular}{|c|c|c|c|c|c|}
\hline & Period & Total & FDI & Portfolio $^{1}$ & Other $^{2}$ \\
\hline \multirow[t]{2}{*}{ Ghana } & 2000-07 & -3.1 & 1.4 & 0.0 & -4.5 \\
\hline & 2010-12 & 7.3 & 8.1 & 1.9 & -2.7 \\
\hline \multirow[t]{2}{*}{ Kenya } & $2000-07$ & 1.9 & 1.2 & -0.1 & 0.8 \\
\hline & 2010-12 & 8.2 & 2.3 & 0.0 & 6.0 \\
\hline \multirow[t]{2}{*}{ Mauritius } & 2000-07 & 2.0 & 1.4 & -0.6 & 1.2 \\
\hline & 2010-12 & 10.7 & 2.4 & 0.0 & 8.4 \\
\hline \multirow[t]{2}{*}{ Mozambique } & $2000-07$ & 8.2 & 4.8 & -0.4 & 3.8 \\
\hline & 2010-12 & 23.8 & 23.8 & 0.0 & 0.1 \\
\hline \multirow[t]{2}{*}{ Nigeria } & 2000-07 & 1.1 & 4.0 & 0.2 & -3.0 \\
\hline & 2010-12 & -2.5 & 2.5 & 2.7 & -7.7 \\
\hline \multirow[t]{2}{*}{ Senegal } & $2000-07$ & 4.3 & 1.2 & 0.2 & 2.9 \\
\hline & 2010-12 & 3.0 & 2.0 & 3.5 & -2.5 \\
\hline \multirow[t]{2}{*}{ Tanzania } & $2000-07$ & 4.7 & 3.9 & 0.0 & 0.7 \\
\hline & 2010-12 & 6.9 & 5.3 & 0.0 & 1.6 \\
\hline \multirow[t]{2}{*}{ Uganda } & 2000-07 & 4.1 & 3.9 & 0.1 & 0.1 \\
\hline & 2010-12 & 7.2 & 5.4 & 0.3 & 1.5 \\
\hline \multirow[t]{2}{*}{ Zambia } & $2000-07$ & 9.9 & 6.4 & 0.3 & 3.2 \\
\hline & 2010-12 & -5.6 & 5.0 & 1.6 & -12.2 \\
\hline \multirow[t]{2}{*}{ SSA - Frontier Markets } & $2000-07$ & 2.0 & 3.3 & 0.1 & -1.4 \\
\hline & 2010-12 & 2.2 & 4.2 & 1.8 & -3.9 \\
\hline \multirow{2}{*}{$\begin{array}{l}\text { Other Emerging } \\
\text { Market Economies }\end{array}$} & $2000-07$ & 2.0 & 2.2 & -0.2 & -0.1 \\
\hline & 2010-12 & 2.1 & 1.9 & 0.9 & -0.7 \\
\hline
\end{tabular}

Source: IMF, World Economic Outlook.

Note: SSA = sub-Saharan Africa.

${ }^{1}$ Portfolio investment includes, in addition to equity securities and debt securities in the form of bonds and notes, money market instruments and financial derivatives such as options.

${ }^{2}$ Other investment is a residual category that includes all financial transactions not covered in direct investment, portfolio investment, or reserve assets, excluding liabilites to official creditors

This share has, however, almost doubled compared to 2000-07. More importantly, over 2010-12, sub-Saharan African frontier markets' net portfolio flows in terms of country gross domestic product outstripped those of emerging and developing economies (about 1.8 percent versus 0.9 percent for emerging and developing countries).

Since June 2013, capital flows in emerging market economies became particularly volatile. Through mid-September 2013, following the announcement by the Federal Reserve chairman about the possible tapering off of unconventional monetary policy, outflows from emerging market mutual funds reached US $\$ 50$ billion (3.9 percent of total), with 
Table 2. Cross-Border Bank-related Flows to Sub-Saharan African Countries (Billions U.S. dollars)

\begin{tabular}{lcccccc}
\hline \multicolumn{5}{c}{ Cross-Border Bank-Related Flows to SSA } \\
\hline & \multicolumn{2}{c}{ Total Loans } & & \multicolumn{2}{c}{ Loans to Nonbanks } \\
\cline { 2 - 3 } \cline { 5 - 6 } & $\mathbf{2 0 0 0 - 0 4}$ & $\mathbf{2 0 1 0 - 1 2}$ & & $\mathbf{2 0 0 0 - 0 4}$ & $\mathbf{2 0 1 0 - 1 2}$ \\
\hline SSA & 50 & 109 & & 39 & 51 \\
SSA (excl. South Africa) & 35 & 82 & & 28 & 39 \\
SSA Frontier Markets & 8 & 36 & & 6 & 25 \\
Other SSA countries (excl. & 28 & 46 & & 22 & 14 \\
South Africa) & & & & \\
\hline
\end{tabular}

Source: Bank for International Settlements, Locational Statistics.

Note: SSA = sub-Saharan Africa.

Figure 3. Sub-Saharan African Frontier Markets External Loans from and Deposits at BIS-reporting Banks

(Billions of U.S. dollars)

a. Banks

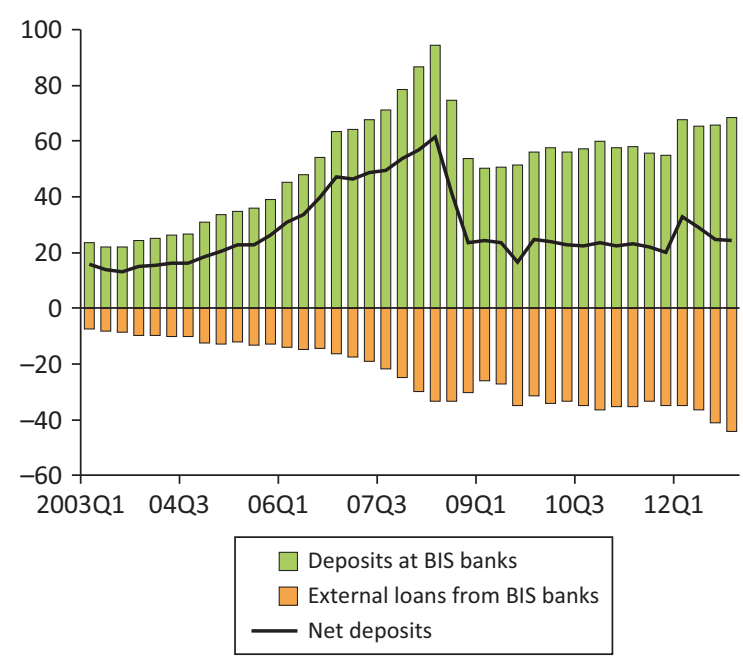

b. Nonbanks

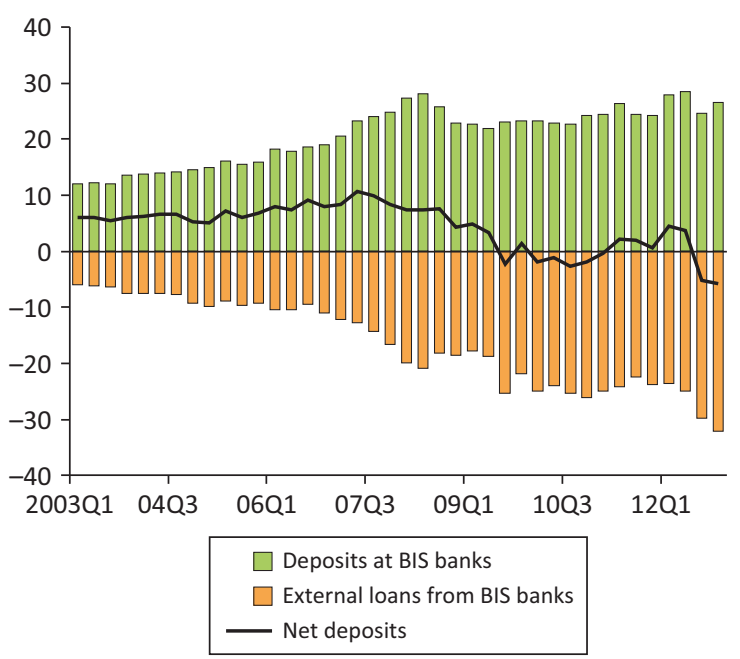

Source: Bank for International Settlement (BIS), Locational Statistics.

roughly US $\$ 23$ billion coming from bond funds (Figure 4). Although the June 2013 emerging market economy selloff was broad-based, the renewed volatility in August that followed some stabilization in July was more selective. Countries with weaker fundamentals such as Brazil, India, South Africa, and Turkey have experienced large depreciations and exchange rate volatilities (Figures 5 and 6) - measured as the percentage change in the exchange rates of their national currency versus the U.S. dollar-sharper declines in equities, greater widening of sovereign spreads and local bond yields, and generally greater outflow from bond funds. 
Figure 4. Trends and Fluctuations in Equity and Bonds Flows to Sub-Saharan African Countries

SSA-Equity Inflows

(cumulative, hundred million U.S. dollars)
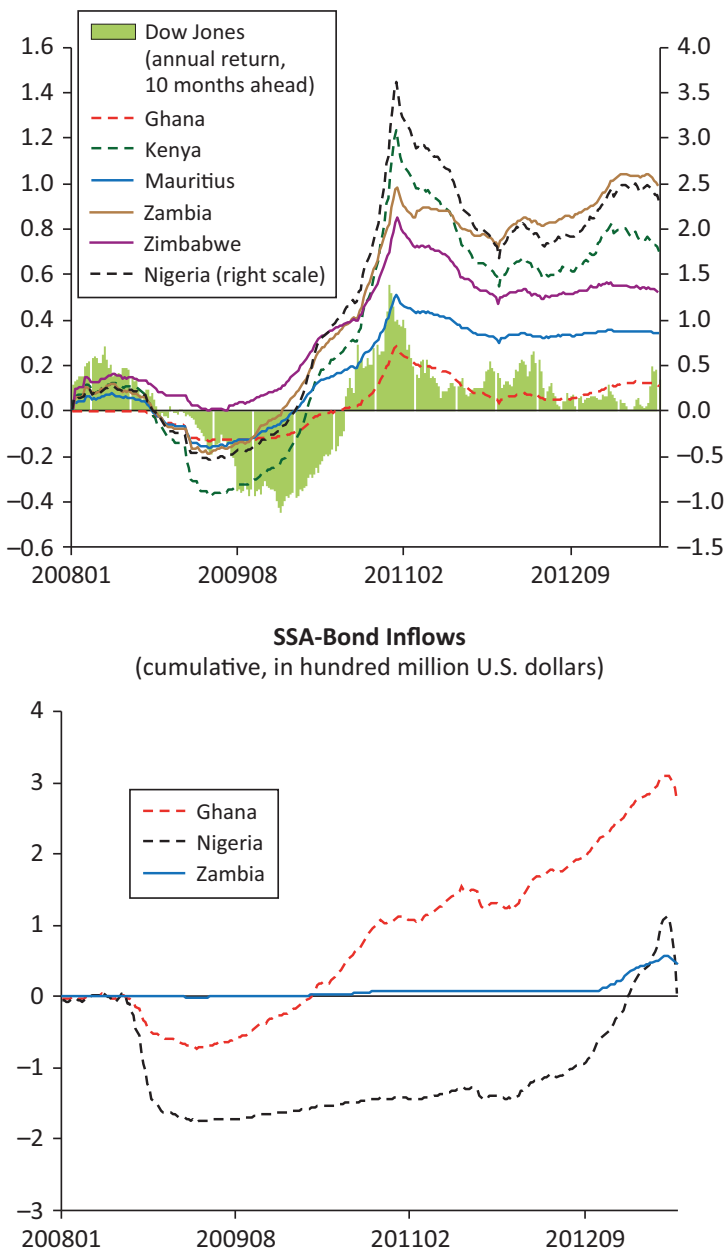

SSA-Equity Flows

(hundred million U.S. dollars)
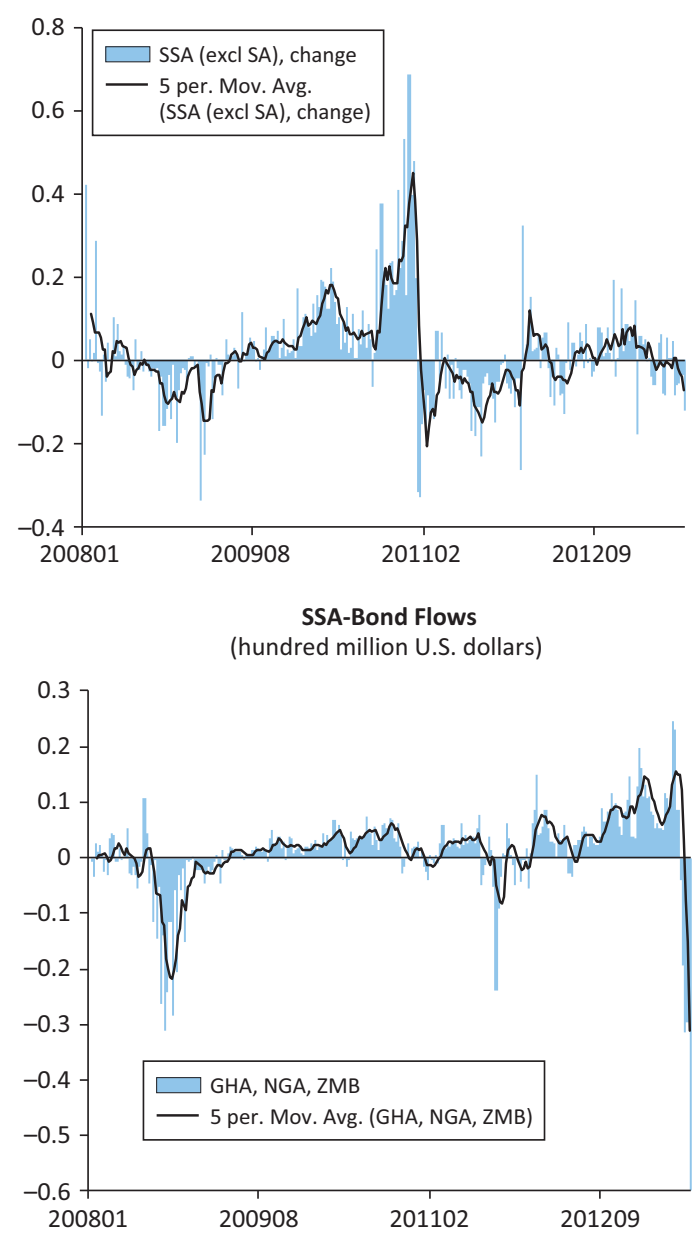

Source: EPFR.

Note: The EPFR database is narrower than that of the IMF's Balance of Payments Statistics. However, it is the source of the most timely and high frequency data. SA = South Africa; SSA = sub-Saharan Africa.

Most sub-Saharan African frontier markets have so far been largely unscathed by the current turmoil affecting emerging and developing economies. In aggregate terms, U.S. dollar-denominated debt of sub-Saharan African frontier markets has not sold off as dramatically as that of the more liquid emerging and developing economies. Between May 22 and late August, the broader emerging market bond index (EMBIG) has declined by 8.5 percent, while the average frontier market bond price has declined by 5 percent (MCM, GMM, August 23). Similarly, sub-Saharan frontier markets' currencies, with the exception of the Ghanaian cedi, have come under relatively little pressure compared to some emerging markets economies (Figures 5 and 6). Some countries, however, such as Ghana and Tanzania, experienced widened bond spreads comparable to those of emerging markets (Figure 7). 
Figure 5. Sub-Saharan African Frontier Markets versus Selected Emerging Market and Developing Economies, Exchange Rate Depreciation (Percent change since January 2013)

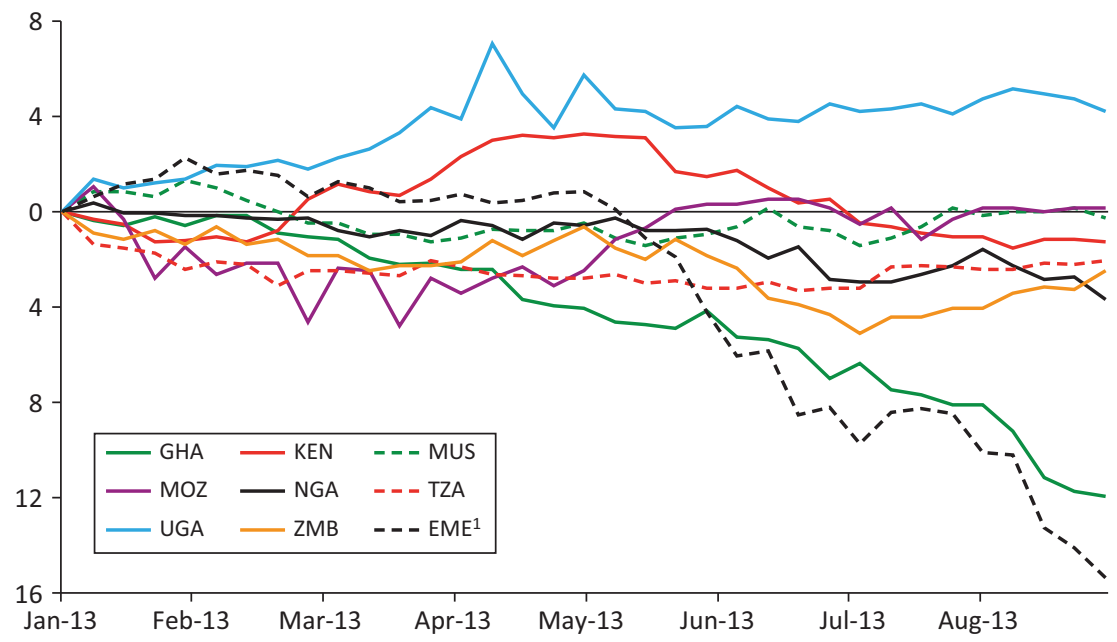

Source: Bloomberg.

Notes: GHA = Ghana; KEN = Kenya; MOZ = Mozambique; MUS = Mauritius; NGA = Nigeria; TZA = Tanzania; UGA = Uganda; ZMB = Zambia.

${ }^{1}$ EME is a weighted average of Brazil, India, South Africa, and Turkey exchange rates

Figure 6. Sub-Saharan Africa versus Selected Emerging Market and Developing Economies, Exchange Rate Volatility, 2013

(Percent change)

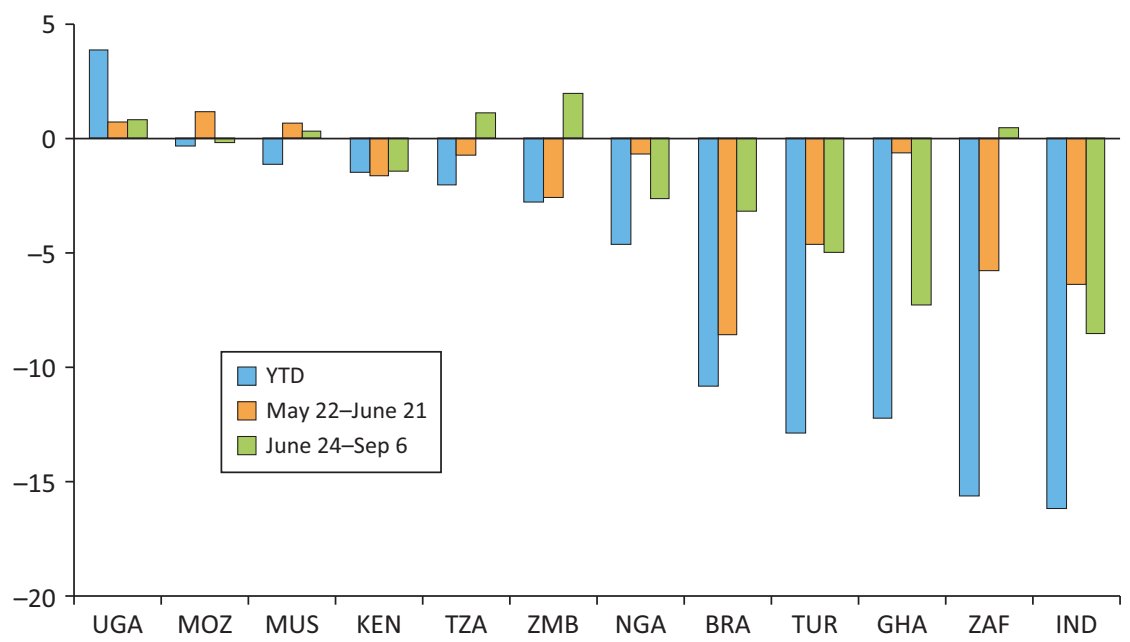

Source: Bloomberg L.P.

Notes: BRA $=$ Brazil; GHA $=$ Ghana $;$ IND $=$ India $;$ KEN $=$ Kenya $; \mathrm{MOZ}=$

Mozambique; MUS = Mauritius; NGA = Nigeria; $T$ TU $=$ Turkey; $\mathrm{TZA}=$ Tanzania;

$\mathrm{UGA}=$ Uganda; $\mathrm{YTD}=$ year to date; ZAF = South Africa; ZMB = Zambia. 
Figure 7. Sub-Saharan Africa Selected Economies, Government Bond Yield to Maturity Spreads to 10-year U.S. Bond, 2013

(Basis points)

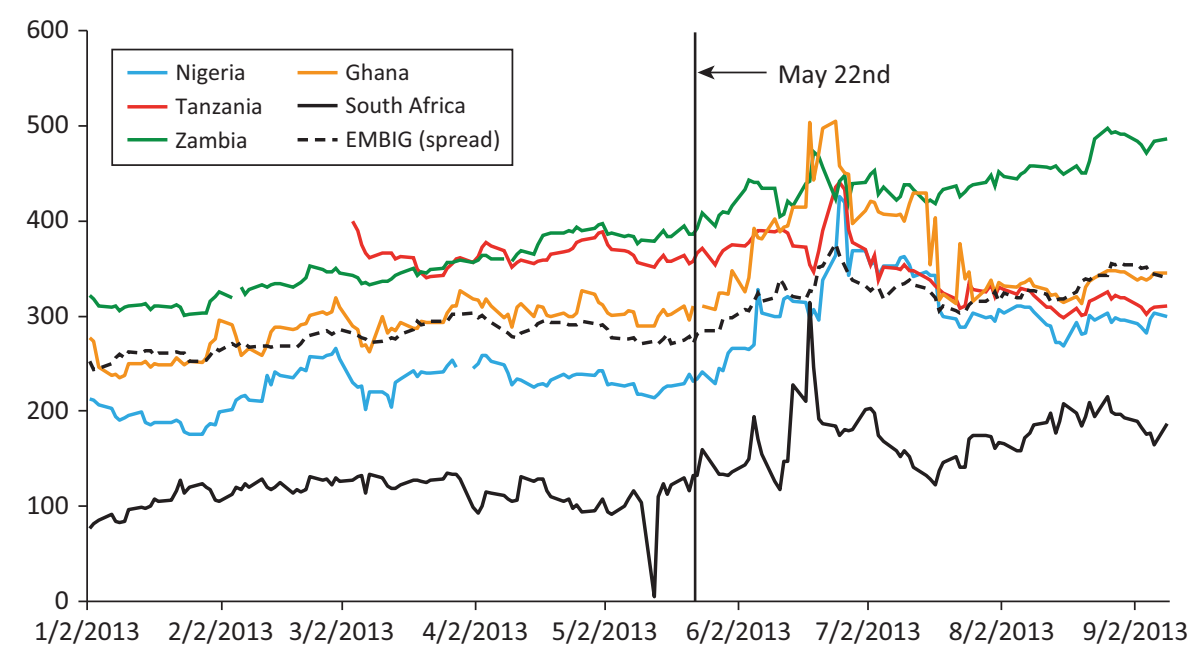

Sources: Bloomberg L.P.; and IMF staff calculations.

The relatively muted impact on some sub-Saharan African frontier markets possibly is due to their liquidity level. Frontier markets represent a tiny fraction of the overall portfolio of dedicated emerging market investors and are very illiquid. So even when dedicated emerging market investors have needed liquidity, they may have been forced to sell the most liquid assets first. Frontier positions tend to be retained for longer. However, in the event that foreign investors do liquidate their positions in such markets, the effect could amplify because there are not enough participants in the domestic market to substitute for the foreign investor.

Where liquidity conditions permitted, investors have differentiated among sub-Saharan African frontier markets based on their economic fundamentals. The more liquid sub-Saharan African frontier market currencies faced relatively more pressures in the second stage of the selloff (June 24-midSeptember) than in the first stage of the selloff (May 22-June 21). Ghana (see Box 2), which is facing rising inflation pressures, deteriorating fiscal balance, and relatively low international reserves, has underperformed other frontier currencies in the period (see Figures 5 and 6). In Nigeria, which is the only sub-Saharan African frontier market that is included in the major emerging market domestic government bond indices, the naira has come under some

\section{Box 2. Ghana's Recent Experience in Portfolio Flows}

Ghana attracted high and stable levels of foreign direct investment of about 8 percent of GDP, underpinned by the discovery and subsequent production of oil in 2011. Oil-related foreign direct investment flows account for two-thirds of total foreign 


\section{Box 2. (concluded)}

Figure 1. Ghana: Domestic Government Debt, by Holder (Percent of total)

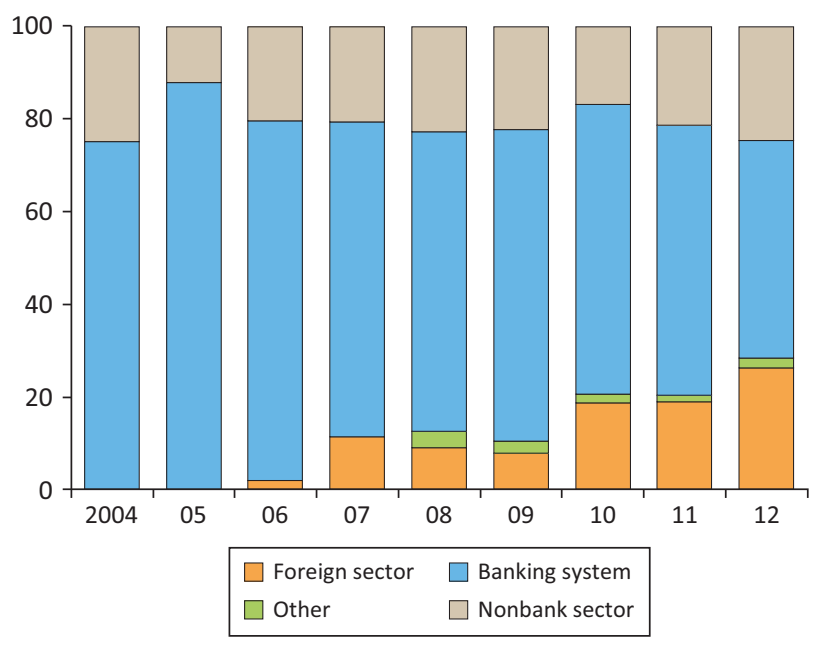

Sources: National authorities; and IMF staff calculations.

direct investment. At 2.8 percent of GDP in 2012, portfolio investments have increased in significance. Portfolio inflows are mostly in medium-term investments, as nonresidents are only allowed to purchase bonds with maturity of at least three years. Ghana sold in August 2013 a bond of US\$1billion, with 10-year maturity at a yield of 8 percent. The yield was higher and the excess bids lower than in other African countries that issued Eurobonds earlier in the year, perhaps partly reflecting the deteriorating financial conditions. Ghana's first 10-year Eurobond was issued in 2007, which was four times oversubscribed and yielded as little as 4 $\frac{1}{2}$ percent in April 2013. That bond had a yield of $8 \frac{1}{2}$ percent at issuance but in an environment of high international interest rates.

Although portfolio flows are supported by strong growth prospects, the abovementioned developments indicate sensitivity to deteriorating fiscal and current account deficit positions of the country and global push factors, which caused emerging market bond turmoil in mid-2013. High domestic interest rates have sustained the interest of foreigners in the medium-term domestic market (about one-third of domestic debt is held by foreigners). ${ }^{1}$ The increased participation of foreigners in the government debt markets could be an additional source of vulnerability resulting from rollover risks. Though the secondary market is rather illiquid, an early redemption or purchase of not yet matured three-year and five-year bonds is possible. Although reserves have been kept roughly stable in recent months, they have fallen below estimates of the optimal reserve level in percent of imports in 2012.

${ }^{1}$ The average exchange rate depreciated by about 17 percent in the first half of 2012 . Consequently, the Bank of Ghana took a number of measures in 2012 to tighten domestic liquidity. Although these measures were successful in stabilizing the currency, they came at the cost of double-digit real interest rates. 
pressure (see Box 3). After May 22, the naira slightly depreciated (see Figures 5 and 6), and there was an increase in government bond yields (see Figure 7). However, this pressure seems to have subsided; the authorities' strategy to use their ample international reserves to keep the naira relatively stable and the strong outlook for oil prices have calmed investors thus far.

The relatively muted impacts in other sub-Saharan African frontier markets may not be sustained if the financial turmoil affecting emerging markets persists. Ghana, Kenya, Tanzania, and Zambia seem to be the most exposed to shifts in foreign investor appetite for risky assets given their large current account deficits and/or deteriorating fiscal balance (Figure 8).

\section{Box 3. Nigeria-Capital Flows and Policy Response}

This box looks into capital flows developments, macroeconomic developments, and authorities' policy response.

Gross private capital flows are estimated to have increased to US\$12.3 billion in 2012 (4.6 percent of GDP) from US $\$ 7.8$ billion (3.4 percent of GDP) in 2010.

Disaggregated data from 2011 showed that the investment to the capital market accounted for 51 percent of total capital importation (foreign direct investment, portfolio investment, and investments liabilities).

These developments contributed to a sharp increase in international reserves (from US $\$ 32$ billion at end-2011 to US\$49 billion at mid-March 2013) as authorities kept the naira-U.S. dollar exchange rate stable. Inflows also induced declining government bond yields (Figure 1) and funded government bond purchases. Inflows also funded purchases of equities and private bonds, resulting in a sharp run-up in stock prices (Figure 2) that exceeded the average increases in stock markets in emerging market economies or advanced economies.

Figure 1. Nigeria: Bond Flows and Government Bond Yield

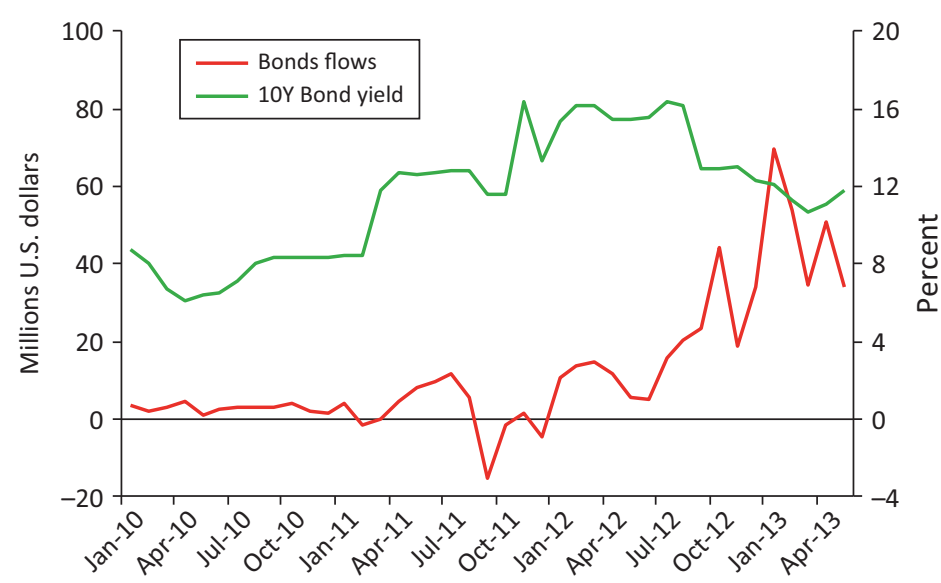

Source: EPFR, Thomson Reuters. 


\section{Box 3. (concluded)}

Figure 2. Nigeria: Equity Flows and Stock Market Index

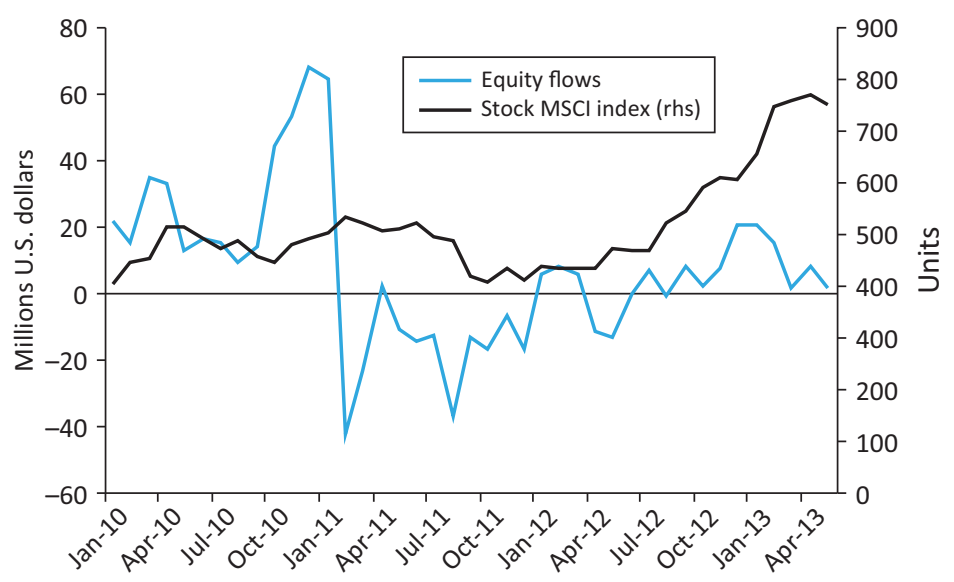

Source: EPFR, Thomson Reuters.

Recently, however, as investor sentiment toward emerging and developing markets has softened, the naira has weakened against the U.S. dollar, and the central bank announced its intention to increase its foreign exchange intervention over the coming months to stabilize the currency. The Central Bank of Nigeria stepped up its defense of the naira during its biweekly foreign exchange auctions; however, the weakening of the naira and the slight decline during June to July of the Nigeria All Share Index may suggest a turn of investor's sentiment. Also, EPFR data are showing some outflows (Figure 4).

Figure 8. Sub-Saharan African Frontier Markets-Twin Deficit (Percent of GDP)

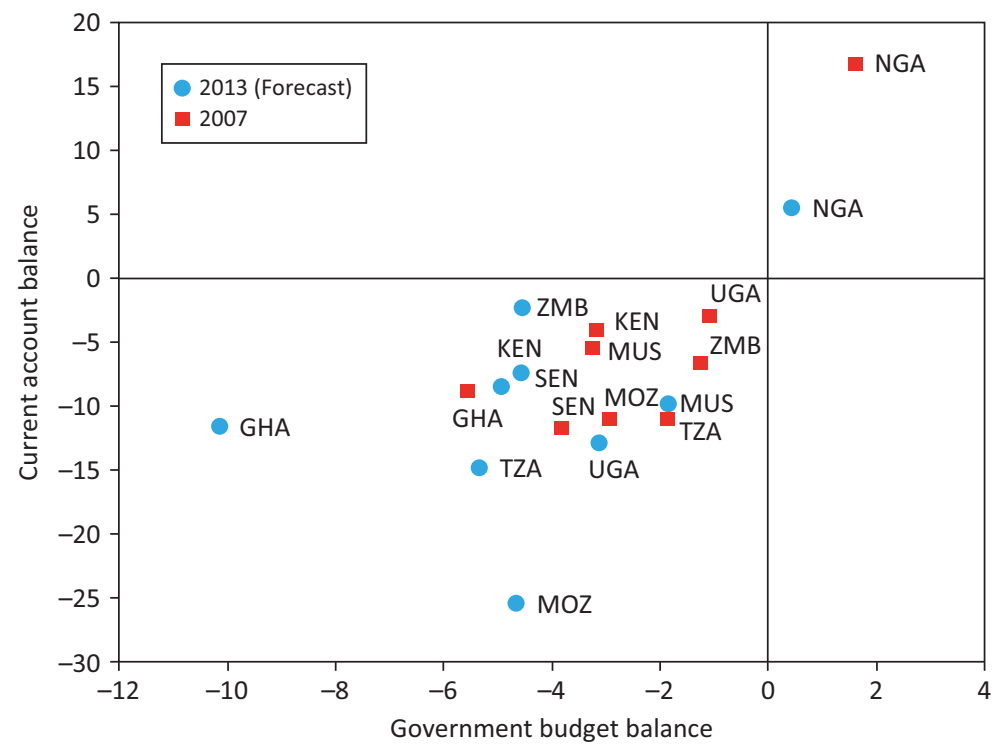

Source: IMF, World Economic Outlook. 


\section{Macroeconomic Impact of Recent Portfolio Capital Flows}

The surge in portfolio flows into some sub-Saharan African frontier markets over the 2011-13:Q1 period had important macroeconomic effects. With the exception of Nigeria, Kenya, and Mauritius, most portfolio inflows may have contributed to expansionary fiscal policies (see Figure 8). Inflows also generally induced declining government bond yields (Figures 9a and 9b),

Figure 9a. Sub-Saharan Africa Frontier Markets-Portfolio Flows and Government Bonds Yields

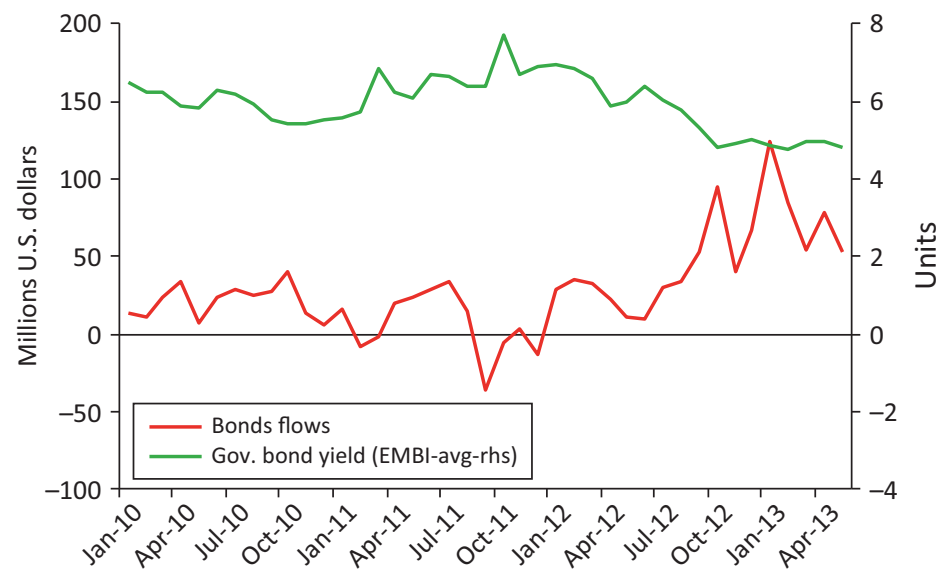

Source: EPFR, Thomson Reuters.

Figure 9b. Sub-Saharan Africa Frontier Markets-Portfolio Flows and Stock Prices Index

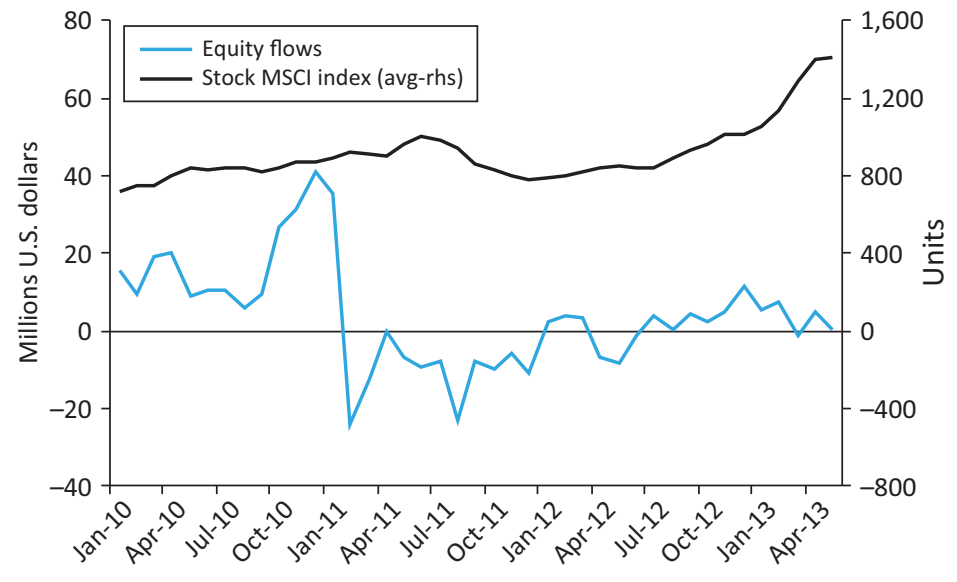

Source: EPFR, Thomson Reuters. 
and funded government bond purchases. In Nigeria and Kenya, inflows also funded purchases of equities and private bonds, resulting in a sharp run-up in stock prices that exceeded the average increases in stock markets in emerging market economies or advanced economies (see Box 3). In some countries, capital inflows, in the form of cross-border bank loans, fueled credit growth (for example, Mauritius). However, in general, private credit growth in subSaharan African frontier markets remained broadly in line with nominal growth of gross domestic product.

Policymakers in sub-Saharan African frontier markets used part of these capital inflows to rebuild international reserves and prevent large appreciations in their currencies (Figure 10). In Nigeria, reserves jumped from 5 months of imports to 6.8 months of imports, between end-2011 and 2013:Q1, while the naira appreciated slightly by about 3 percent against the U.S. dollar during that period. In some countries, central banks were confronted with the task of ensuring that the increase in liquidity arising from the capital inflows did not subvert their inflation and other monetary policy objectives. Thus, in Nigeria, although policy rates were kept unchanged, the authorities raised the cash reserve requirement. In a number of countries, central banks also needed to step up open market operations to sterilize the capital inflows. However, in light of concerns about large sterilization costs and/or weak central bank capital positions, Zambia (Box 4) and Mauritius at times allowed the buildup of large excess liquidity.

Figure 10. Sub-Saharan Africa Frontier Markets: Net Portfolio Flows and Gross International Reserves (Billions of U.S. dollars)

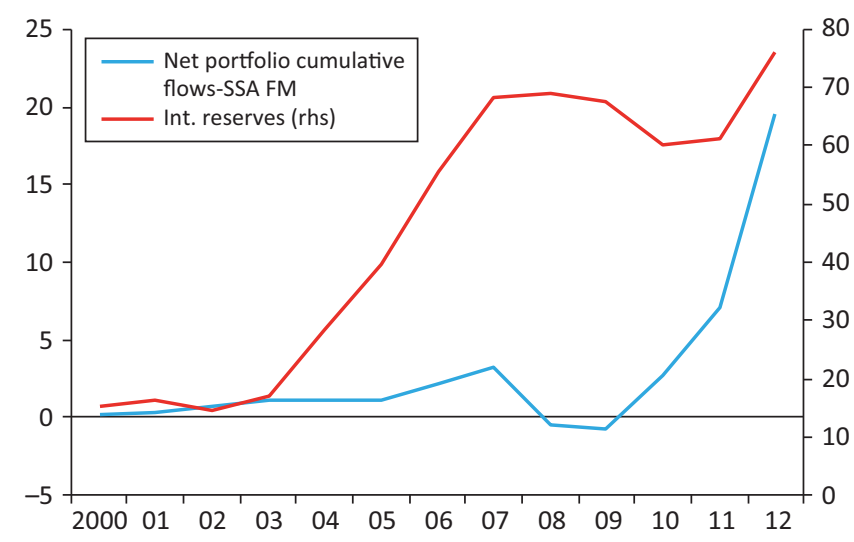

Source: IMF, World Economic Outlook, and International Financial Statistics. 


\section{Box 4. Zambia-Copper and Capital}

After a sharp drop in 2009, capital flows increased, primarily led by foreign direct investment inflows in the mining sector, from US $\$ 0.4$ billion in 2009 to US $\$ 1$ billion (5 percent of GDP) in 2012. Foreign direct investment flows have responded to rising copper prices but also to Zambia's relatively favorable business environment, compared with other countries in the region. In September 2012, Zambia issued successfully its first sovereign Eurobond (10-year dollar-denominated bullet bond of US $\$ 750$ million). Moreover, foreign investment in government securities in the domestic market picked up in mid-2012 with foreign holdings amounting to US\$250 million in May 2013 (about 10 percent of Zambia's international reserves), increasing foreign holdings of government securities within one year maturity from $2 \frac{1}{2}$ percent to about 8 percent. Equity flows remain small.

The bulk of the increase in foreign investment in government securities in the domestic market has been in shorter-term treasury bills. These flows are driven by investors' search for yield and increased risk appetite. Higher interest rates on Zambian government securities since September 2012 paired with a relatively stable exchange rate underpinned investors' interest in the absence of significant controls on banking and portfolio flows. Owing to the still limited size of short-term flows, no policies have been taken in response to the recent capital inflows. However, the Bank of Zambia has demonstrated its willingness to act when it introduced during the global financial crisis a limit on foreigners' short-term borrowing in local currency.

Table 1. Government Bond Issues

\begin{tabular}{lllcccc}
\hline Date & Issuer & Rating & Size (US\$ mil.) & Maturity (Years) & Coupon (\%) & Yield at Issue (\%) \\
\hline Oct-11 & Namibia & BBB- & 500 & 10 & 5.5 & 5.835 \\
Sep-12 & Zambia & B+ & 750 & 10 & 5.375 & 5.625 \\
May-13 & Rwanda & B & 400 & 10 & 6.625 & 6.875 \\
Jul-13 & Nigeria & BB- & 500 & 10 & 6.375 & 6.625 \\
Aug-13 & Ghana & B+ & 1,000 & 10 & 7.875 & 8 \\
Dec-13 & Gabon & BB- & 1,500 & 10 & 6.375 & 6.477 \\
\hline
\end{tabular}


Managing volatile capital flows has not yet created major policy challenges in most sub-Saharan African frontier markets. Looking ahead, however, given the trend toward deeper integration with global financial markets, subSaharan African frontier markets are likely to become increasingly vulnerable to global financial shocks. In that context, a key emerging lesson is the need for coherent macroeconomic frameworks that are credible and well communicated. Experience in the more troubled countries and discussions of expected Federal Reserve tapering with sub-Saharan central banks in East Africa highlight the need for clarity in the monetary framework, avoiding loose talk on the imposition of capital controls, which may lead to deteriorating confidence and worsen the situation.

How prepared are sub-Saharan African frontier markets to handle the consequences of increased integration with global capital markets? Managing volatile capital flows typically requires a combination of (i) macroeconomic policies, which should be primary adjustment policies; (ii) macroprudential policies, prudential tools designed to limit systemic financial risk; and (iii) capital flow measures (CFMs), which should not be substitute for policy adjustment, but could play a temporary role, buying time to implement more fundamental adjustment. The specific policy mix depends, among others factors, on existing macroeconomic conditions, the quality of domestic prudential regulation, and related institutional development.

\section{Macroeconomic Policies}

Whenever possible, macroeconomic policies should be the primary instruments used to minimize any undesirable macroeconomic effects from volatile capital flows (IMF, 2013c). However, ensuring maximum macroeconomic policy flexibility requires the maintenance of overall macroeconomic stability along with adequate buffers. These conditions are typically not always present and hence the recommended mix of 
macroeconomic policies is likely to differ across countries. In particular, some sub-Saharan African frontier markets exhibit areas of macroeconomic vulnerability with limited depth of financial and credit markets, constraining their monetary policy options. In addition, timely policy implementation is critical, with adequate and timely data on sources and types of capital flows and on other macroeconomic indicators. In this context, sub-Saharan African frontier markets will need to invest in building their capacity to collect and analyze data on capital flows and, more generally, capital and financial accounts of the balance of payments as well as asset prices, particularly real estate prices.

In considering an appropriate policy response for a given country, several factors must be taken into account. These include (i) a current assessment of the exchange rate and competitiveness; (ii) analysis of foreign exchange reserve adequacy-both in terms of import cover and in terms of short-term debt and other liabilities cover - and also of the alignment of the exchange rate with fundamentals ${ }^{5}$ (Table 3); (iii) the cyclical position of a country, including its output gap and the extent of inflation pressures; (iv) the extent of risks for asset bubbles; and (v) the balance sheet conditions of banks, corporate entities, and financial intermediaries. Thus, for example, Nigeria, on the one hand, with a healthy international reserve buffer and a currency

Table 3. Real Exchange and International Reserves Performance

\begin{tabular}{lcc}
\hline Country & $\begin{array}{c}\text { 2012 Exchange Rate } \\
\text { Assessment }\end{array}$ & $\begin{array}{c}\text { End-2012 Reserves Months } \\
\text { of Imports }\end{array}$ \\
\hline Ghana & + & 2.8 \\
Kenya & 0 & 3.8 \\
Mauritius & 0 & 4.3 \\
Mozambique & 0 & 3.3 \\
Nigeria & 0 & 5.7 \\
Senegal ${ }^{1}$ & 0 & 5.2 \\
Tanzania & 0 & 3.4 \\
Uganda & 0 & 4.2 \\
Zambia & 0 & 3.3 \\
\hline
\end{tabular}

Source: IMF, African Department database and country staff reports.

Note: + overvaluation of national currency, 0 means real exchange real aligned with economic fundamentals.

${ }^{1}$ West African Economic and Monetary Union reserves in months of imports excluding intraregional trade.

\footnotetext{
${ }^{5}$ With a few exceptions, the real exchange rates in frontier markets have remained aligned with fundamentals despite the surge in capital inflows. Until end-2012, only Ghana seems to have an overvalued exchange rate while no other appreciation pressures are recorded for the rest of sub-Saharan African frontier markets economies. Moreover, real exchange rates weakened recently in most of the frontier markets countries.
} 
generally in line with fundamentals, can choose to intervene in the foreign exchange market as part of its strategy to manage capital outflows caused by a perceived temporary episode of global risk aversion (IMF, 2012). Its robust economic growth and still high inflation also suggests that some tightening of monetary conditions might also be employed. On the other hand, Ghana, with much lower reserves, and large fiscal and current account deficits, would need to allow its currency to adjust, while also substantially tightening monetary and fiscal policies to attenuate the capital outflow and reduce its need for foreign financing, respectively (IMF, 2013a).

\section{Macroprudential Measures}

Apart from complicating macroeconomic management, volatile capital flows may increase financial system risks. Capital inflow surges may jeopardize banking system stability if they facilitate excessive credit growth by banks or foster asset/ liability currency mismatches. Surges might also fuel asset price bubbles (for example, in real estate or in the equities market). The Nigerian banking crisis of 2009 was, in part, fueled by foreign borrowing by banks, the proceeds of which were used to invest in the stock market. When the stock market bubble burst, a number of banks became insolvent. Therefore, there is also an important role for macroprudential policies to play in managing capital flows.

While macroeconomic policies can limit the adverse impact of volatile capital flows, they cannot completely insulate sub-Saharan African frontier markets from major global financial shocks. To limit negative spillovers, policies that promote sound and stable domestic financial systems are important. Healthy local banking systems would provide a buffer as they did after the global financial crisis. In this context, reported capital adequacy ratios exceed regulatory norms in most sub-Saharan African frontier markets, whereas recognized nonperforming loans are relatively low compared with other low-income countries. Nevertheless, as sub-Saharan African frontier markets become more integrated into the global financial system, it will be important for policymakers and supervisors to better tailor prudential regulations to address systemic risks arising from such integration and build capacity to monitor and assess risks associated with cross-border activities.

Macroprudential instruments can be grouped in three broad categories: (i) tools to address threats from excessive credit expansion in the system (countercyclical capital requirements, dynamic provisioning, increased risk weights); (ii) tools to address key implications of systemic financial risk (caps on foreign currency lending, limits on maturity mismatches, limits on net open currency positions); and (iii) tools to mitigate structural vulnerabilities and limit spillovers from banking stress (bank resolution requirements, disclosures for markets and institutions targeting systemic risks). 
Sub-Saharan African frontier markets have started to adopt macroprudential measures in varying degrees (see Box 5). In Nigeria, the authorities recently reviewed the risk weights on certain industry exposures in the computation of the capital adequacy ratio and have also limited bank investments in the stock market. In Uganda, currently the authorities are designing contingency plans to

\section{Box 5. Capital Flows Management Measures in Sub-Saharan African Frontier Markets}

The type and extent of capital flows management measures have varied widely, reflecting countries' specific circumstances. The following types of measures are used:

\section{Measures aimed at managing capital inflows:}

Restrictions on nonresident purchase of government securities: Only one of the region's frontier market economy countries applies restrictions on all purchase of government securities by nonresidents (Tanzania); another restricts only purchases of government securities of less than three years (Ghana); and two others (Nigeria and Kenya) apply selective restrictions on nonresident purchases of securities.

Maximum total primary issuance of bonds held by nonresidents: Zimbabwe imposes a maximum cap of 35 percent.

Maximum total share of national companies held by nonresidents: Three countries apply these types of measures: Kenya (60 percent), Tanzania (60 percent), and Zimbabwe (35 percent at primary issuance, and approval required for participation in the secondary market).

Maximum on share purchased by individual investors: In Tanzania, individual investors may not acquire more than 1 percent of an issue and institutional investors no more than 10 percent.

Minimum holding period: In Tanzania, there is a minimum holding period of three months for all shares and securities purchased locally by nonresidents.

Limits to direct or indirect foreign exchange exposure: In Tanzania, owing to regulations of the Bank of Tanzania (October 2011), banks are no longer able to enter into swaps or forward sales with nonresidents, and even spot transactions in foreign exchange have to reflect an economic interest. In Kenya, swaps are restricted to maturities longer than one month.

Approval required prior to capital transactions with nonresidents: In Mozambique, all transactions with nonresidents require approval by the central bank. Zimbabwe requires approval from the Exchange Control to invest new inflows of funds in money market instruments.

\section{Measures aimed at managing capital outflows:}

Approval prior to transaction: In one of the frontier market economies (Senegal), approval by the Ministry of Finance is required for virtually all capital outflows except for amortization of debt and repayments of short-term loans. As mentioned before, by limiting outflows, this policy may also discourage capital inflows.

Request of accounting and/ or tax records: Two countries-Tanzania and Zambia-request presentation of audited accounts and/or compliance with tax obligations for the repatriation of capital and associated income. 
deal with excessive inflows through macroprudential means. However, in subSaharan African frontier markets, where financial systems are becoming more complex, effective macroprudential measure policies will require the authorities to strengthen technical capacity and improve information. For example, in these economies, as in emerging and developing economies, nonbank financial institutions (such as pension funds and insurance companies) are becoming systemically important, and nonbank financial institutions can account for a significant share of the financial system's total assets, and be a source of funding to banks. Linkages among financial institutions are increasing and becoming more complex; financial institutions are becoming more integrated with the global economy, and cross-border banking activities are growing rapidly. However, supervisory processes have traditionally focused on compliance to regulations for individual banks instead of monitoring systemic risks. In addition, supervisory resources, including qualified staff and availability of analytical tools, are limited (Beck, Maimbo, Faye, and Triki, 2011). And limited high-frequency data on the concentration of risks within the system limit the efficient monitoring of systemic vulnerabilities.

Strengthening supervisory capabilities for an enhanced use of macroprudential policies would require the following: (i) developing ways to monitor a risk buildup; (ii) setting in place indicators and analytical tools to detect when risks are about to materialize; and (iii) using macroprudential tools in a timely manner (IMF, 2011b). For instance, the recent Financial Sector Assessment Program for Nigeria recommended that the authorities continue to strengthen consolidated supervision of financial entities and improve capacity for cross-border supervision, given the increase in cross-border operations of Nigerian and regional banks. Mauritius also recently started joint supervisory exercises for important financial institutions, and improved significantly the coverage and quality of its balance-ofpayments statistics, better capturing flows related to the offshore banking sector. Although a number of countries have developed high-frequency indicators of economic activity as part of an exercise in improving their monetary policy frameworks, similar data and reporting requirements on capital flows characteristics (for example, origin, destination, and type of investment, maturity, and so on), which would be essential for close monitoring and analysis of emerging risks, are largely absent. ${ }^{6}$

Indeed, in certain circumstances, attempts to apply more sophisticated macroprudential measures in limited capacity settings may even backfire.

\footnotetext{
${ }^{6}$ In the 2012 Article IV consultation (IMF, 2012), the Nigerian authorities indicated that they were mindful of the risk of capital flow reversals and thus were closely monitoring the surge in inflows, especially by keeping track of the maturity distribution of the securities that were being purchased.
} 
For example, employing countercyclical capital provisioning requirement in the absence of high-frequency data, or a countercyclical limit on banks' net open foreign exchange positions in the absence of timely and high-quality data on the type and maturity of banks' foreign exchange assets and liabilities could amplify business cycles and create foreign exchange liquidity crunches that negatively affect bank stability.

\section{Capital Flow Management Measures}

In the context of the recent capital inflows period, the IMF has revisited the toolkit for addressing the risks from surges in capital flow. In its "institutional view" (IMF, 2013b), the IMF notes that in certain circumstances CFMs can play a complementary role in supporting macroeconomic adjustment and safeguarding financial stability. In particular, CFMs may be temporarily appropriate if the room for adjusting monetary, fiscal, and exchange rate policies is constrained - either through limited macroeconomic space or possible destabilizing balance sheet effects in the financial sector. CFMs may also buy time in cases where policy adjustments take time to implement. However, CFMs should be temporary and not substitute for necessary macroeconomic adjustment or financial stability measures.

Most sub-Saharan African countries have only partially liberalized their capital accounts, and remaining restrictions may impact on capital flows even though they were not designed for that purpose (see Box 6). Measures in place in frontier markets include residency-based or currency-based limits (tax or regulation) on capital flows. For example, in Tanzania, nonresident purchases of domestic treasury securities are not permitted, whereas in Ghana and Kenya, there are restrictions limiting nonresident purchases of government securities to longer maturity instruments. Restrictions on outflows also exist and generally also pre-date the 2008-09 global crisis. While outflow CFMs on nonresidents are typically less onerous than those on residents, this is not always the case. In Senegal, for example, most capital outflows would require approval prior to transactions with nonresidents. In Tanzania, there is a minimum holding period of three months for all equity shares purchased locally by nonresidents.

In the context of a restrictive capital account framework, the use of additional CFMs for capital account management may be more difficult than otherwise. With an already complex regulatory framework, additional measures may have negative feedback effects on investor confidence. When faced with a surge of capital flows, frontier markets may therefore want to be mindful of potential drawbacks, and carefully assess the costs and benefits of CFMs. Costs could include damaging effects on future inflows and reputational risks for the country's investment environment. These potential drawbacks will 


\section{Box 6. Examples of Macroprudential Policies}

\begin{tabular}{ll}
\hline Country & Macroprudential Policies \\
\hline Ghana & In 2009 \\
& - Foreign and local currency deposits are subject to a 9 percent reserve requirement in \\
& domestic currency. \\
& - Reserve balance must be held with the Bank of Ghana. \\
& - Daily single foreign currency exposure limit was reduced from 15 to 10 percent of the \\
& capital base. \\
Kenya & - Capital requirements are relatively high to prepare banks for overall risks. \\
& - Households do not borrow in foreign currency, except for a small segment of the \\
& mortgage market. \\
Mozambique & - The limited impact of private capital inflows on the overall liquidity conditions has not \\
& called for specific macroprudential measures. \\
Nigeria & - Exposure to a particular industry within a sector is in excess of 20 percent of total \\
& credit facilities of a bank the risk weight of the entire portfolio in that industry shall be \\
Senegal & - No traditional macroprudential regulations have been employed. \\
Tanzania & - In late 2011 net open position on foreign exchange was reduced. \\
Uganda & - Ongoing design of contingency plans to deal with excessive inflows through \\
& macroprudential means.
\end{tabular}

Source: Country authorities.

be particularly large in the case where a CFM would limit capital outflows. ${ }^{7}$ Hence for those frontier markets with a reputation for a relatively open capital account (for example, Nigeria and Mauritius) and other sub-Saharan African frontier markets seeking to build such a reputation, the costs of introducing new CFMs may be relatively high.

However, even when CFMs may be desirable, implementation issues arise. Effectiveness will depend on country-specific policy frameworks and institutional settings. In sub-Saharan African frontier markets with relatively unsophisticated financial market structures, controls may in fact be more effective than in more developed financial markets, where complex financial instruments might make it easier to circumvent controls. At the same time, institutional capacity and information constraints in frontier markets will generally prevent effective monitoring and enforcement of capital restrictions, hence strongly undermine the likely effectiveness of CFMs.

\footnotetext{
${ }^{7}$ For example, the temptation to use restrictions on bank deposits in low-capacity settings as tools to control capital outflows would not be advisable, as they can severely disrupt economic activity, confidence in the financial system, and prospects for financial deepening.
} 
Both the impact on the investment climate and implantation constraints argue for only very restricted use of the $\mathrm{CFM}^{8}$ as a tool in SSA frontier markets. It is generally recommended that any new CFMs should be temporary, and scaled back when the capital flow pressures abate. In addition, CFMs should avoid leading to external payments arrears or default particularly in sovereign debt, which could undermine relations with creditors and damage the international trade and payments system. In crisis or near crisis situations, there could be a temporary role for introducing CFMs on outflows as part of a broader policy package to address the underlying cause of the crisis.

\footnotetext{
${ }^{8}$ At times, CFMs and macroprudential measures may overlap. Policy tools could be seen as both a CFM and a macroprudential policy. For example, a restriction on banks' foreign borrowing through a levy on bank foreign exchange inflows or required reserve on banks' foreign exchange liabilities would aim to limit capital inflows or slow domestic credit. In any way, these policies should be seen as supporting effective supervision and complementing appropriate sound macroeconomic policies (IMF, 2013b).
} 


\section{Conclusions}

In the past three years, foreign portfolio flows to sub-Saharan Africa have grown considerably. Sub-Saharan African frontier markets were the main beneficiaries, and, for the most part, the current bout of global financial market turbulence has so far left most of these countries relatively unscathed. For those countries left unscathed, this, in part, reflects their relatively illiquid financial markets but also their still strong fundamentals and prospects. However, this muted impact may not be sustained, and risks of contagion and possible reversals remain if the global turmoil persists. Looking ahead, given the clear trend toward their deeper integration with global financial markets, sub-Saharan African frontier markets are likely to become increasingly vulnerable to global financial shocks. The appropriate combination of policies for addressing these risks would depend on country circumstances, and the toolkit would need to include macroeconomic and prudential policies. In that context, the following will need to be strengthened:

- Improving data. A recurring theme of this chapter is the need to improve data quality and timeliness. In a number of countries, the official data on private capital portfolio flows and stocks are based on defective surveys that may suffer from only partial coverage (for example, omitting nonbanks) or poor quality (for example, inadequate validation of transactions reported by banks). Article IV staff reports for most subSaharan African frontier markets have highlighted the need to strengthen balance-of-payments data, including the coverage of cross-border private capital flows and stocks.

- Enhancing macroeconomic and financial policies. Managing capital flows is more likely to be successful if it is supported by sound fiscal, monetary, and exchange rate policies and adequate fiscal and international reserve buffers. This would allow more policy room to mitigate any negative macroeconomic effects of capital flow surges or reversals, as has been seen in the case of Nigeria thus far. In addition, in the current episode of global financial market turbulence, investors have tended to punish 
more those countries - including among sub-Saharan African frontier markets - with the worse economic fundamentals.

- Improving capacity to effectively use macroprudential policies. Macroprudential measures are important to prevent the buildup of systemic financial sector risks that may arise from volatile capital flows. Sub-Saharan African frontier markets have implemented various such measures, such as limits on banks' open foreign exchange positions. However, ensuring the effectiveness of macroprudential policies requires progress in developing ways to monitor a systemic risk buildup and using macroprudential tools in a timely manner. In sub-Saharan African frontier markets, supervisory resources, including qualified staff, the availability of high-frequency data, and analytical tools to assess systemic risks are limited and will need to be strengthened.

- Improving the toolkit of capital flow management measures. The IMF has indicated that, when the room for adjusting macroeconomic policies is limited, capital flow measures (CFMs) may be considered to temper volatile flows. In the case of sub-Saharan African frontier markets, however, effective implementation would require significant improvements in institutional capacity to monitor flows and enforce regulations, given the often porous nature of existing capital controls. More importantly, the imposition of new CFMs, especially on outflows, would require evaluating possible negative effects on future inflows, such as the damage to further financial sector deepening and improved relations with international investors. In this context, any new CFMs on outflows should be considered only as a last resort in response to financial crisis situations. 


\section{Annex: Econometric Analysis of Drivers of Portfolio Flows to Sub-Saharan African Frontier Markets}

The regressions reported in Table A.1 are run on an annual panel data covering the period 1991-2012 for selected emerging and frontier markets. The dependent variable is defined as the ratio of portfolio liabilities (nonresident purchases of domestic assets net of sales) to GDP. The use of lagged regressors helps to minimize potential of endogeneity. The regression includes variables aimed to capture push factors such as the U.S. Treasury bill interest rates, and global risk (VIX), as well as several pull factors such as the inflation level, fiscal balance, gross public debt, output growth, change in reserves, and the stock market development. A stepwise approach was employed to explore the significance of alternative pull variables (many of them are likely collinear). Random effects were used to allow the inclusion of a dummy for sub-Saharan African frontier markets. Running the regressions for sub-Saharan African frontier markets alone produced no statistically significant relationships, likely because of poor data quality and the small size of the sample.

Another set of regressions focusing on sub-Saharan African frontier markets was run using quarterly data and disaggregating portfolio flows in equity and bonds flows (Table A.2). The dependent variables are based on EPFR data, defined for each country as the flows into equity and bond funds of the country, divided by the stock at the beginning of the quarter. A crisis dummy is equal to 1 from 2008:Q4 onward. The estimation is limited by the fact that most pull factors are not available on a quarterly basis. Quarterly output growth was only available for three countries in the sample. Ghana and Nigeria were selected as a subsample because these countries have experienced larger portfolio inflows. 


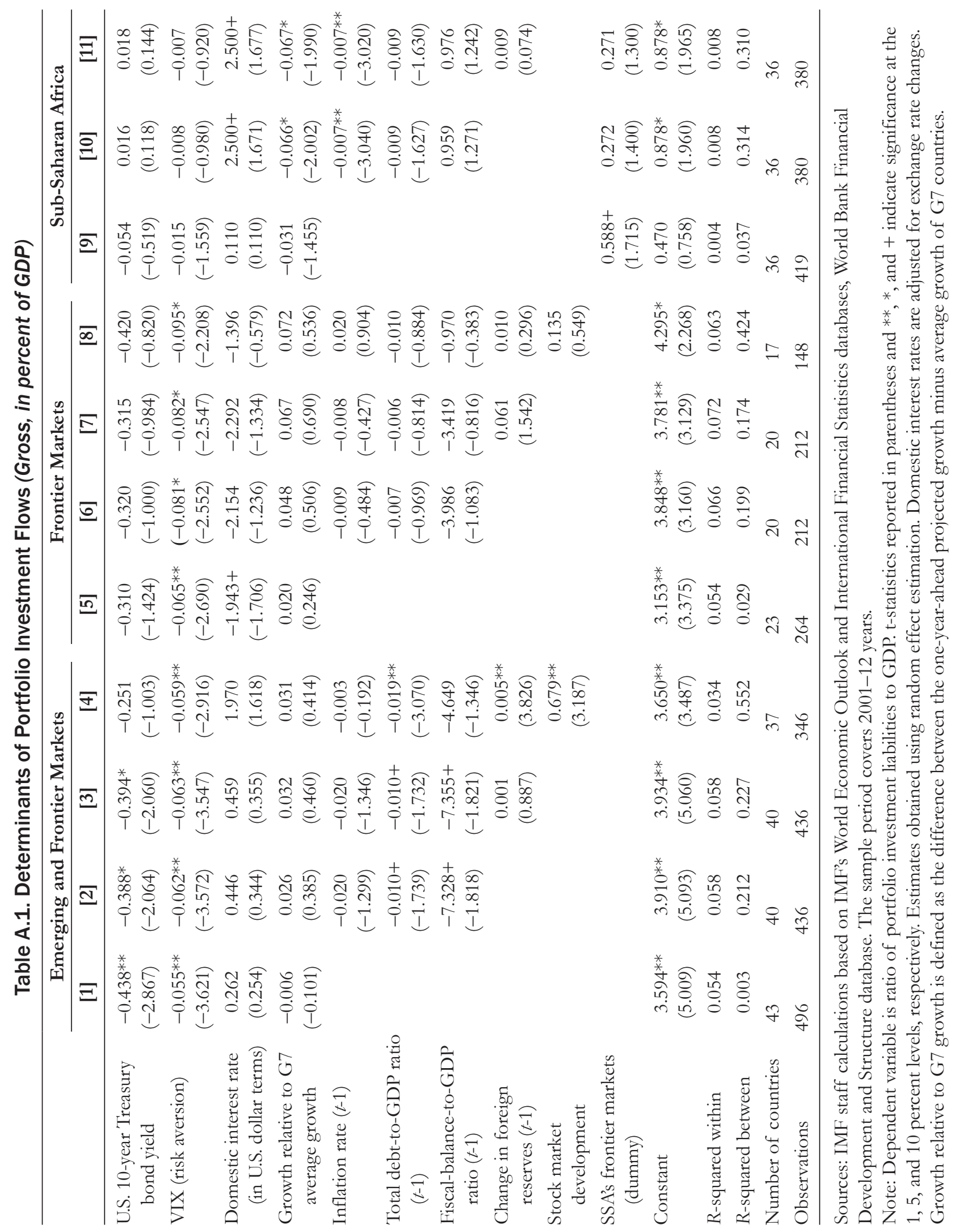


Table A.2. Determinants of Equity and Bond Flows in Sub-Saharan Africa

\begin{tabular}{|c|c|c|c|c|c|c|c|c|c|c|c|}
\hline \multirow[b]{3}{*}{ VIX } & \multicolumn{4}{|c|}{ Portfolio } & \multicolumn{4}{|c|}{ Equities } & \multicolumn{3}{|c|}{ Bonds } \\
\hline & \multicolumn{2}{|c|}{$\begin{array}{c}\text { Sub- } \\
\text { Saharan } \\
\text { Africa }\end{array}$} & \multicolumn{2}{|c|}{$\begin{array}{c}\text { Nigeria } \\
\text { and Ghana }\end{array}$} & \multicolumn{2}{|c|}{$\begin{array}{c}\text { Sub- } \\
\text { Saharan } \\
\text { Africa }\end{array}$} & \multicolumn{2}{|c|}{$\begin{array}{c}\text { Nigeria } \\
\text { and Ghana }\end{array}$} & \multirow{2}{*}{$\begin{array}{c}\begin{array}{c}\text { Sub- } \\
\text { Saharan } \\
\text { Africa }\end{array} \\
-* * *\end{array}$} & \multicolumn{2}{|c|}{$\begin{array}{c}\text { Nigeria } \\
\text { and Ghana }\end{array}$} \\
\hline & - *** & - *** & -*** & -*** & - *** & - *** & -*** & -*** & & -*** & -*** \\
\hline Crisis dummy & & $+* * *$ & & $+* * *$ & & + & & $+* * *$ & & & $+* * *$ \\
\hline Output growth & & & & & & & & - & & & + \\
\hline Constant & $+* * *$ & $+* * *$ & $+* * *$ & $+* * *$ & $+* * *$ & $+* * *$ & $+* * *$ & $+* * *$ & $+* * *$ & $+* * *$ & $+* * *$ \\
\hline $\mathrm{R}$-squared & 0.22 & 0.27 & 0.29 & 0.34 & 0.02 & 0.02 & 0.23 & 0.30 & 0.17 & 0.20 & 0.29 \\
\hline Countries & 5 & 5 & 2 & 2 & 11 & 11 & 2 & 2 & 5 & 2 & 2 \\
\hline Observations & 126 & 126 & 53 & 53 & 478 & 478 & 92 & 47 & 160 & 66 & 60 \\
\hline
\end{tabular}

Source: IMF staff calculations.

Notes: $(+,-)$ indicate the sign of the coefficient, ${ }^{* *},{ }^{* *}$, and $*$ indicate significance at the 1,5 , and 10 percent levels, respectively. 



\section{References}

Beck, Thorsten, Samuel Munzele Maimbo, Issa Faye, and Thouraya Triki, 2011, Financing Africa (Through the Crisis and Beyond). (Washington: The International Bank for Reconstruction and Development/ The World Bank).

International Monetary Fund, 2011a, Regional Economic Outlook: Sub-Sabaran Africa (Washington, April).

— , 2011b, World Economic Outlook (Washington, September). , 2012, "2012 Nigeria Article IV Consultation Staff Report" (Washington).

__, 2013a, "2013 Ghana Article IV Consultation Staff Report” (Washington).

— 2013b, "Key Aspects of Macroprudential Policy," Board Paper (Washington, June).

_ , 2013c, "The Liberalization and Management of Capital Flows: An Institutional View," Board Paper (Washington, June). 
